\title{
CAPABILITY OF FIELD SPECTROSCOPY FOR THE ASSESSMENT OF SOIL CONTAMINATION IN SOUTHERN PORT-SAID GOVERNORATE
}

\author{
Rasha S.M. Awes ${ }^{1 *}$, A.B.A. Belal ${ }^{1}$, M.A.A. Hassan ${ }^{2}$, S.A.M. Abd El-Azeem ${ }^{2}$ \\ 1. Nat. Author. Remote Sensing and Space Sci., Egypt \\ 2. Soil Sci. Dept., Fac. Agric., Suez Canal Univ., Egypt
}

Received: 30/03/2017 ; Accepted: 21/05/2017

\begin{abstract}
Soil contamination by heavy metals considers as main environmental problem in the world, most of them have toxic effects on plant and microorganisms in soil when permissible concentration levels are exceeded. The objective of the current work is detection of soil contamination in southern Port-said Governorate using spectroscopy Vis-NIR (350-2500 nm). To predict contaminated soil through Vis-NIR 58 different sites were selected in southern Port-said Governorate. Spectroradiometer ASD was used to measure the spectral reflectance of soil site. Three heavy metals $\mathrm{Pb}, \mathrm{Mn}$ and $\mathrm{Cd}$ have been selected to achieve this purpose. Stepwise multiple linear regression (SMLR) was used to construct calibration models. The concentrations of heavy metals were estimated with high accuracy where, the models were validated based on the independent validation. The results illustrated that, $\mathrm{R}^{2}$ was recorded $0.94,0.70$ and 0.66 for $\mathrm{Cd}, \mathrm{Mn}$ and $\mathrm{Pb}$ respectively. The concentration of soil contamination by $\mathrm{Cd}, \mathrm{Mn}$, and $\mathrm{Pb}$ are under the threshold. except area contaminated with Cd is (10791.08) faddans. However, Remote Sensing and Geographic Information System (GIS) are provide detailed spatial information on soil contamination, it's rapidly and inexpensive.
\end{abstract}

Key words: Soil contamination, spectroscopy, heavy metals.

\section{INTRODUCTION}

The contamination of natural environment components such as soil, sediment, water and biota by heavy metals is a major, worldwide concern because of their toxicity. Heavy metals concentration is considered as one of the keys which, affects directly on soil quality and crop quality which, effected on human health. The use of wastewater for irrigation fulfills certain socioeconomic and environmental goals such as increasing production or profits and diminishing of wastewater discharge to the environment. On the other hand, wastewater is considered a source of harmful pathogenic diseases and the contamination of surface and ground water (Hamilton et al., 2007).

Wastewater contains a variety of pollutants including pathogens and heavy metals which

\footnotetext{
*orresponding author: Tel. : +201069550663

E-mail address: rashasaide@yahoo.com
}

can potentially harm the environment as well as human and animal health (Qadir et al., 2007). Approximately one million acre in the Nile delta depends on drainage water for irrigation (Abu Zeid, 2011). Reusing this drainage water may cause adverse effects on soil, crop, animal, and human health. One of the most polluted drains in Egypt is Bahr El-Baqar (Omran and Abd ElRazek, 2012). Bahr El-Baqar drain receives untreated waste water starting from east of Cairo, at the discharge point of El-Gebel ElAsfar and then joined by Belbeis drain, down to the confluence with Qalubiya drain. The length of the main drain is $170 \mathrm{~km}$ discharges in ElManzala Lake and has two main branches, Qalubyia drain and Bilbies drain. It receives and carries the greatest part of wastewater (about 3 BCM/year) into Lake Manzala through a very densely populated area of the Eastern Delta 
passing through Qalubyia, Sharkia, Ismailia and Port Said Governorates. Four main sources of pollutants which cause deterioration in Bahr ElBaqar are: The industrial activities in Shoubra El-Khema including metal production, food processing, detergents and soaps manufacturing, textile finishing and paper production; Industrial activities in Zagazig area; Waste water discharged from Belbeis drain to Bahr El-Baqar; and Domestic discharge received from rural areas around Bahr El-Baqar drain. Assia et al. (2004) showed that Bahr El-Baqar drain transports water to the Lake Manzala northeastern edge of the Nile Delta .The discharge of industrial, agricultural and municipal wastewaters in Bahr El-Bakar drain led to contamination of these soils. These soils receive many kinds of pollutants especially heavy metals such as lead, cadmium, nickel, and mercury which are considered the most hazardous. Saad (1997) concluded that 58\% of the total drainage water of Bahr El-Baqar drain comes from agricultural drainage, $2 \%$ from industrial drainage and $40 \%$ from domestic and commercial drainage.

Ramadan (2003) studied the concentration of ( $\mathrm{Zn}, \mathrm{Pb}, \mathrm{Cd}$ and $\mathrm{Hg}$ ) in the soils of the eastern sector of Lake Manzala and reported that the concentrations of $\mathrm{Zn}$ were within the standard critical range of 70 to $400 \mathrm{mg} / \mathrm{kg}$. Lead concentration was also within the standard critical range in soils of 30 to $300 \mathrm{mg} / \mathrm{kg}$. The same applies on $\mathrm{Cd}$ concentrations in soils showing a range of values (5 to $9 \mathrm{mg} / \mathrm{kg}$ ) with the standard critical range $(3-8 \mathrm{mg} / \mathrm{kg})$. Mean $\mathrm{Hg}$ concentration in soils showed that it is the most epidemic pollutant with a range of 40 to $245 \mathrm{mg} / \mathrm{kg}$ much higher than the standard critical range $(0.3-5 \mathrm{mg} / \mathrm{kg})$.The Manzala Lake is influenced by fresh water runoff from the land via drains and canals. This water enriched the lagoons with nutrients including phosphate, nitrate and silicate. In addition, some drains discharge considerable amount of sewage and industrial wastes directly into the lagoons (Loranger and Zayed, 1994).

Geochemical remote sensing technologies provide a fast, macro way to access to the Earth's surface chemical information, thereby has been widely used in many fields such as environmental geochemistry and soil sciences.
As powerful tool for monitoring vegetation stress, hyper spectral remote sensing technique is increasingly being used, directly or indirectly to monitor the status of heavy metal pollution (Kooistra et al., 2001). Researchers have shown that can accurately determine soil properties and heavy metals in visible-near-infrared (VNIR) spectroscopy in the spectral range 400-2500 nm under laboratory conditions. It can be almost continuously, and relatively less expensive and faster than traditional wet chemical measurements, and save time compared to standard laboratory tests (Yun, 2003).

Multiple linear regression (MLR) is one of several methods to band selection for derivative heavy metals and soil properties using reflectance field spectrometer. MLR is a classical method that creates a linear combination of the spectral values at every single wavelength to correlate as closely as possible to the dependent reference values. The regression coefficients are estimated by minimizing the error between predicted and observed response values in a least squares sense (Schwartz et al., 2011).

Objectives of these search detection from capahbility of spectrometer reflectance data to detection soil contamination and soil properties in Southern Port-said Governorate. Development Multi Linear regression for relationships between reflectance data and soil contamination and soil properties in the studied area. Validate Multi Linear regression of spectral reflectance data which detect heavy metal concentration and soil properties through the results of soil contamination from traditional method (atomic absorption) and wavelet-fractal analysis spectrometer (VNIR SWIR) and soil contamination. Production spatial distribution maps for soil contamination and soil properties to deleting contamination areas in Southern soil Port-said Governorate. Create Hazard map for heavy metals contamination in southern soil port- saidGovernorate.

\section{MATERIALS AND METHODS}

\section{Study Area and Methodology}

The study area is located between longitude $32^{\circ} 17^{\prime} 39.56^{\prime \prime}$ and $32^{\circ} 17^{\prime} 39.16 " \mathrm{E}$ and latitude $30^{\circ} 58^{\prime} 45.64^{\prime \prime} \mathrm{N} 30^{\circ} 58^{\prime} 34.56^{\prime \prime N}$. It is situated 
north-east of Cairo, east of the Nile Delta, south of Manzala lake and west of Suez Canal as shown in Fig. 1. The study area has several environmental problems related to increasing soil pollution. The area attributed as an arid region where the minimum annualized temperature is $11.2^{\circ} \mathrm{C}$ and is recorded during January while the maximum annualized temperature is $31^{\circ} \mathrm{C}$ and is recorded during August. The relative humidity varies throughout the year, ranging from 67.2 to $82.87 \%$. Visibility differs from ranged between 8.5 and $10.3 \mathrm{~km}$. Where the lowest values are observed in December, whereas the highest values are recorded in July. The minimum annual wind speed is $12.3 \mathrm{~km} / \mathrm{hr}$., and is recorded during November while the maximum annual wind speed is $18.3 \mathrm{~km} / \mathrm{hr}$., and is recorded during March. The investigation area is described by (Mohamed et al., 2011).

The total surface area of the study area is approximately (51527.58 faddans). A reconnaissance visit was performed for the study area to get different landscape features; land-use and land-cover patterns. The extensive field surveys were guided with a Global Positioning System (GPS) receiver. Fifty eight different sites were selected randomly in southern Port-said Governorate where is found homogeneity in physiographic unites, and give each sample chance to represent population sample.

\section{Laboratory Analyses}

Soil Electric conductivity (EC), organic matter $(\mathrm{OM}), \mathrm{pH}$, soluble cations and anions, $\mathrm{CaCO}_{3}$, cation exchange capacity (CEC), and Particle size distribution was determined according to (Bandyopadhyay, 2007). The concentration selected heavy metals were determined using an atomic absorption spectrophotometer (Shimadzu, AA-6800). Fig. 2 shows the overall methodology used in this study.

\section{Spectroscopy Analysis}

The ASD FieldSpec FR spectroradiometer samples spectral radiance across the wavelength range $0.35-2.5 \mathrm{~mm}$ with spectral resolution of $0.003 \mathrm{~mm}$ at ffi $0.7 \mathrm{~mm}$ and $0.01 \mathrm{~mm}$ at ffi 1.4 and $2.1 \mathrm{~mm}$. Its nominal noise equivalent changes in radiance (neL) are $1.410-9 \mathrm{~W} \mathrm{cm-2}$ $\mathrm{nm}-1 \mathrm{sr}-1$ at $0.7 \mathrm{~mm}, 2.410-9 \mathrm{~W}$ cm-2 nm-1 sr- 1 at $1.4 \mathrm{~mm}$ and $8.810-9 \mathrm{~W}$ cm-2 nm-1 sr-1 at $2.1 \mathrm{~mm}$. The contact probe (Fig. 7) has a stable light source integrated with the mount for the spectrormeter optic cable five spectra of each sample were obtained. All of the measurements were made with the sensor located directly over the center of the sample. The mean of the five spectra was determined to provide a single spectral value. ViewSpec software used to convert spectral data from DN data to reflectance data and export it to ASCII text files, which used easily in Microsoft Excel.

\section{Geostatistical Analysis}

Geostatistical methodology uses the semivariogram to quantify the spatial variation of a regionalized variable. The semi-variogram, $\gamma$ (h), measures the variability mean between two points $\mathrm{X}$ and $\mathrm{X}+\mathrm{h}$, as a function of their distance $h$. The experimental variogram is calculated for several lag distances. It is then generally fitted with a theoretical model, such as a spherical or exponential model. These models provide information about the structure of the spatial variation as well as the input parameters for spatial prediction by kriging. soil contamination (Lead, Cadmium, Manganese) were entered into a field-scale GIS and interlayer data analytical tools were utilized to quantify spatially dependent relationships. Ordinary Kriging (O.K) is one of the most basic kriging methods (Meul and Van Meirvenne, 2003). At an unsampled Location $\mathrm{X} 0, \mathrm{Z}$ is estimated by:

$\mathrm{Z} \times(\mathrm{X} 0)=\Sigma \lambda \mathrm{iZ}(\mathrm{X}$ i $)$

$\mathrm{i}=1$

Where:

$\mathrm{Z} \times(\mathrm{X} 0)$ is the estimated value of the random Variables (RV) Z at the unsampled location X0 and $\lambda \mathrm{i}$ are the $\mathrm{n}$ weights assigned to the observation points $Z$ (xi). The weights $\lambda i$ sum to one to assure unbiased conditions and they are found by minimizing the estimation variance. The $\mathrm{RV} \mathrm{Z}(\mathrm{x})$ can be decomposed into a trend component $\mathrm{m}(\mathrm{x})$ and a residual Component $\mathrm{R}$ (x):

$$
Z(X)=m(X)+R(X)
$$

OK assumes stationarity of the mean and considers $\mathrm{m}(\mathrm{x})$ to be a constant, but of unknown 


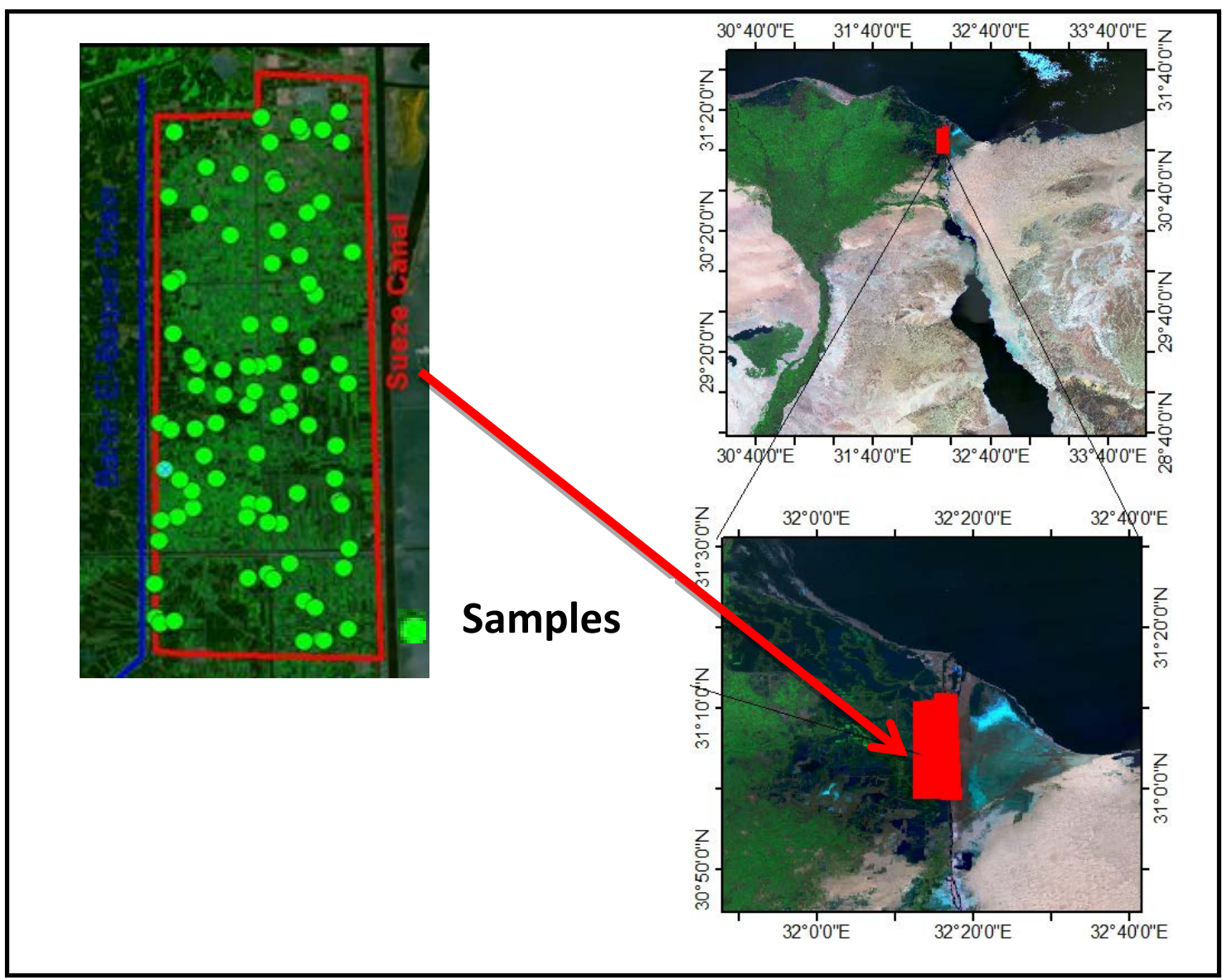

Fig. 1. Location map of the study area

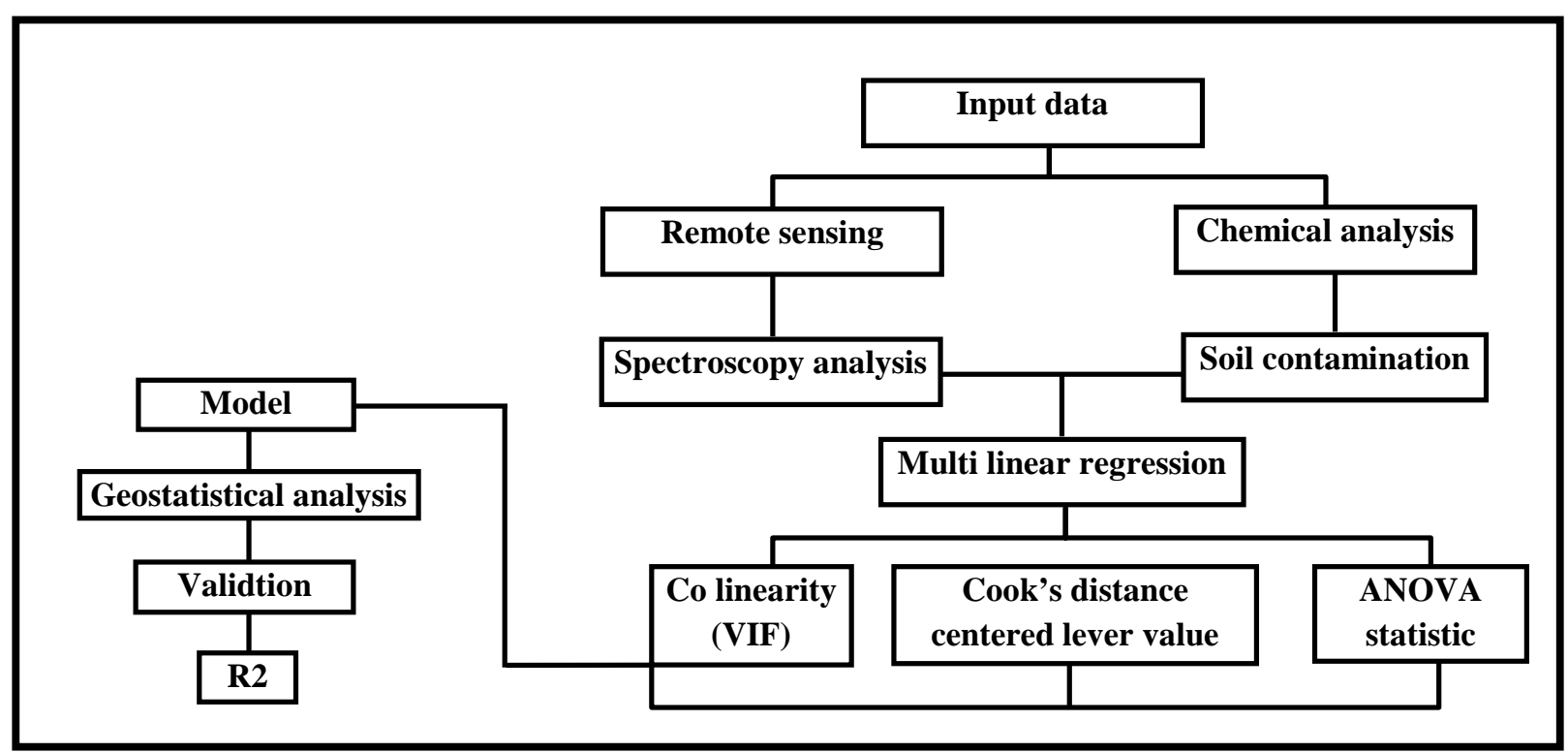

Fig. 2. Flowchart for the research methodology steps 
value. Nonstationary conditions are taken into account by restricting the domain of stationarity to a local neighbourhood and moving it across the study area. The residual component $\mathrm{R}(\mathrm{x})$ is modeled as a stationary RV with zero mean and under the assumption of intrinsic stationarity, its spatial dependence is given by the semivariance $\gamma R(h)$ :

$\gamma \mathrm{R}(\mathrm{h})=\frac{1}{2 \mathrm{~N}(\mathrm{~h}) \mathrm{i}=1} \quad \mathrm{~N} \sum(\mathrm{h})[\{\mathrm{R}(\mathrm{x}+\mathrm{h})-\mathrm{R}(\mathrm{x})\} 2]$ (3)

Assuming a constant mean $\mathrm{m}(\mathrm{x})$, Eq. (3) is equivalent to:

$\left.\gamma(\mathrm{h})=\frac{1}{2 \mathrm{~N}(\mathrm{~h}) \mathrm{i}=1} \quad \mathrm{~N} \sum(\mathrm{h})[\mathrm{Z}(\mathrm{x}+\mathrm{h})-\mathrm{Z}(\mathrm{x})\} 2\right]$

\section{Multi Linear Regression (MLR)}

The simplest way to express a relationship between variables is a linear relationship. The linear expression is as follows :

$\mathrm{Y}=\mathrm{a}+\mathrm{b}_{1} \mathrm{X}_{1}+\mathrm{b}_{2} \mathrm{X}_{2}+\ldots \ldots+\mathrm{b}_{2} \mathrm{X}_{\mathrm{n}}$

Where:

$\mathrm{Y}$ is the heavy metals concentration explained by wave lengthes and soil properties $X_{1}, X_{2}$ and $\mathrm{X}_{\mathrm{n}}, \mathrm{a}$ is intercept and $\mathrm{b}_{1}, \mathrm{~b}_{2}$ and $\mathrm{b}_{\mathrm{n}}$ are the regression coefficients (Cohen et al., 2003).

This can be tested first for linear regression analysis. This means if the independent variable (soil contamination, soil properties) decreases or increases then the depended variable (spectra) will either decreases or increase. The relationship should be tested for the following: ANOVA statistic, Collinearity Cook's distance and Centred Lever Value.

\section{RESULTS AND DISCUSSION}

\section{Soil Physico-Chemical Characteristics and Spatial Distribution of Selected Heavy Metals}

Table 1 show some physicochemical characteristics and heavy metal levels in soil. The concentration of each heavy metal is always controlled by different soil parameters e.g. (soil $\mathrm{pH}$, organic matter, calcium carbonates and cation exchange capacity), However the current ECe values ranged between 0.561 and $2.91 \mathrm{dSm}^{-1}$ which consider non saline soil of the study area.
These results indicate the good management of these soils with leaching many times as it used as fish ponds. The organic matter varied from 0.51 to $2.9 \%$. These soils are used as fishponds and have some residual of organic feeding on soil surface which is the reason why the OM content is high. Soil organic matter plays an important role not only in iron oxidation and reduction but also it forms complexes with any soluble iron that is released. The organic matter extract, doubtless, chelates with iron and holds it for a time in a soluble condition and thus it can be transported within the plant tissues. The cation exchange capacity varied from 17.2 to $25.3 \mathrm{~mol} / \mathrm{kg}$. $\mathrm{pH}$ varied from 7.2 to 7.6 this indicate that the heavy metals in this soil is complex compound and $\mathrm{pHC}_{\mathrm{a}} \mathrm{Cl}_{2}$ was greater than the unit of $\mathrm{pHw}$. This indicate that the soil has positive charges on their surfaces which have amorphous iron oxides and organic matter. The $\mathrm{CaCO}_{3}$ (\%) ranged from 5.7 to $40.2 \%$, and the highest values related to their content the samples from shells in the field. As shown in Table 1 the texture of soils in the studied area were sandy loam or sandy. This indicates that the rate of increase dispose of heavy metals in the soil.

According the geostatistical analysis approach as shown in Fig. 3, contamination soils are characterized by slightly pollution as lead values around 0.2-13.4 ppm. Manganese values ranged from 194.4 to $402.4 \mathrm{ppm}$, while cadmium exceed threshold which ranged between 1.6-4.2 ppm, all heavy metals have been recorded rise in values lied in southern section. The discharge of industrial, agricultural and municipal wastewaters in Bahr Elbakar drain led to contamination of these soils. These soils receive many kinds of pollutants especially heavy metals such as lead, cadmium, nickel, and mercury which are considered the most hazardous (Park and Shin, 2006).

\section{Spectral Reflectance Of Selected Heavy Metals}

Spectroradiometer (ASD Field Spec) is used to evaluate quantitative analysis of heavy metals where, using stepwise multi-linear regression procedure between the concentration of a given constituent for soil contamination and the spectral response which measured by 
Table 1. Soil characteristics of the study area

\begin{tabular}{|c|c|c|c|c|c|c|c|c|c|c|}
\hline \multirow{2}{*}{$\begin{array}{c}\text { Sample } \\
\text { No. }\end{array}$} & \multirow{2}{*}{$\mathbf{p H}_{\mathrm{w}}$} & \multirow{2}{*}{$\begin{array}{c}\mathbf{p H} \\
\mathrm{CaCl}_{2}\end{array}$} & \multirow{2}{*}{$\begin{array}{c}\text { EC } \\
\mathrm{dSm}^{-1}\end{array}$} & \multirow{2}{*}{$\begin{array}{c}\mathrm{CEC} \\
\mathrm{mol}_{\mathrm{c}} \mathrm{Kg}^{-1}\end{array}$} & \multirow{2}{*}{$\begin{array}{c}\mathrm{CaCO}_{3} \\
(\%) \\
\end{array}$} & \multirow{2}{*}{$\begin{array}{l}\text { OM } \\
(\%)\end{array}$} & \multicolumn{3}{|c|}{ Menanical composition (\%) } & \multirow[t]{2}{*}{ Texture } \\
\hline & & & & & & & silt & Clay & Sand & \\
\hline 1 & 7.45 & 8.08 & 1.66 & 22.1 & 18.0 & 1.69 & 30 & 15.4 & 54.6 & loam_sandy \\
\hline 2 & 7.35 & 8.23 & 0.659 & 19.5 & 21.3 & 0.51 & 6.7 & 13.3 & 80 & sandy_loam \\
\hline 3 & 7.53 & 8.17 & 1.2 & 19.6 & 33.6 & 1.92 & 10 & 15 & 75 & sandy_loam \\
\hline $3 b$ & 7.52 & 8.18 & 1.01 & 24.5 & 31.0 & 2.05 & 11.9 & 16.7 & 71.4 & sandy_clay_loam \\
\hline 4 & 7.6 & 7.96 & 1.55 & 22.1 & 34.4 & 2.02 & 6 & 29.7 & 64.3 & sandy_clay_loam \\
\hline 5 & 7.31 & 8.19 & 2.91 & 20.2 & 18.6 & 2.50 & 13 & 32 & 55 & Loam \\
\hline 6 & 7.32 & 7.92 & 1.85 & 20.4 & 17.9 & 1.84 & 46.3 & 15.7 & 38 & sandy_clay_loam \\
\hline 7 & 7.45 & 7.91 & 2.2 & 21.5 & 26.0 & 2.70 & 8.8 & 29.4 & 61.8 & Loam \\
\hline 8 & 7.32 & 8.12 & 1.12 & 21.3 & 21.3 & 1.52 & 41.1 & 11.8 & 47.1 & sandy_loam \\
\hline 9 & 7.4 & 8.05 & 1.5 & 22.5 & 25.2 & 2.05 & 33.8 & 6.8 & 59.4 & sandy_loam \\
\hline 10 & 7.51 & 8.16 & 1.12 & 21.1 & 24.5 & 1.92 & 27.5 & 11 & 61.5 & sandy_loam \\
\hline 10b & 7.33 & 8.2 & 0.822 & 22.9 & 12.2 & 1.77 & 27.1 & 16.7 & 56.2 & Loam \\
\hline 11 & 7.26 & 8.21 & 1.11 & 21.3 & 18.6 & 2.02 & 40.8 & 10.2 & 49 & sandy_loam \\
\hline 12 & 7.53 & 8.02 & 1.02 & 19.5 & 37.1 & 2.02 & 25.3 & 6.3 & 68.4 & sandy_clay_loam \\
\hline 13 & 7.32 & 7.93 & 1.709 & 19.6 & 12.8 & 2.07 & 6.6 & 32.9 & 60.5 & Loam \\
\hline 14 & 7.45 & 8.09 & 2.22 & 19.6 & 22.9 & 2.40 & 12.2 & 36.6 & 51.2 & sandy_clay_loam \\
\hline 15 & 7.56 & 8.1 & 0.565 & 18.7 & 39.1 & 2.30 & 29.7 & 24.7 & 45.6 & sandy_clay_loam \\
\hline 16 & 7.45 & 8 & 1.65 & 19.3 & 32.3 & 2.35 & 22.2 & 22.2 & 55.6 & sandy_loam \\
\hline 17 & 7.55 & 8.11 & 1.5 & 20.1 & 35.3 & 1.59 & 17.4 & 29.1 & 53.5 & sandy_loam \\
\hline 18 & 7.43 & 8.1 & 2.3 & 21 & 13.3 & 1.95 & 36.7 & 7.6 & 55.7 & sandy_clay_loam \\
\hline 19 & 7.44 & 7.76 & 1.981 & 21.3 & 12.6 & 2.53 & 38.9 & 5.6 & 55.5 & Loam \\
\hline 20 & 7.63 & 8.01 & 1.65 & 21.5 & 40.2 & 2.27 & 13.7 & 20.5 & 65.8 & Loam \\
\hline 21 & 7.51 & 7.84 & 1.709 & 21 & 18.0 & 2.38 & 40.6 & 16 & 43.4 & clay_loam \\
\hline 22 & 7.43 & 7.95 & 2.6 & 19.5 & 16.1 & 1.64 & 33 & 17 & 50 & clay_loam \\
\hline 23 & 7.33 & 8.08 & 2.5 & 19.6 & 10.2 & 2.40 & 19.6 & 39.2 & 41.2 & clay_loam \\
\hline 24 & 7.28 & 7.97 & 2.7 & 18.7 & 6.5 & 2.21 & 19.2 & 38.5 & 42.3 & Loam \\
\hline 25 & 7.3 & 7.82 & 2.18 & 19.4 & 9.6 & 2.90 & 45.5 & 10.1 & 44.4 & Loam \\
\hline 26 & 7.34 & 7.93 & 2.3 & 18.7 & 22.6 & 2.10 & 47.1 & 9.4 & 43.5 & sandy_loam \\
\hline 27 & 7.37 & 7.91 & 2.3 & 18.9 & 11.2 & 1.84 & 26.7 & 6.7 & 66.6 & sandy_loam \\
\hline 28 & 7.43 & 8.19 & 1.71 & 18.5 & 17.7 & 0.91 & 25.8 & 12.4 & 61.8 & sandy_loam \\
\hline 29 & 7.33 & 8.16 & 2.7 & 18.4 & 9.6 & 2.27 & 22.5 & 19.1 & 58.4 & sandy_loam \\
\hline 30 & 7.29 & 7.92 & 1.452 & 17.6 & 6.2 & 1.09 & 26.5 & 11.8 & 61.7 & sandy_loam \\
\hline 31 & 7.34 & 8.19 & 1.028 & 17.2 & 9.6 & 1.47 & 23.3 & 7.8 & 68.9 & sandy_loam \\
\hline 32 & 7.23 & 8.05 & 2.5 & 17.6 & 5.7 & 1.95 & 45 & 7.5 & 47.5 & sandy_loam \\
\hline 33 & 7.24 & 7.92 & 2.28 & 18 & 6.2 & 1.29 & 41.8 & 5.3 & 52.9 & Loam \\
\hline 34 & 7.22 & 8.21 & 2.4 & 18.2 & 5.7 & 1.49 & 36.8 & 17 & 46.2 & Loam \\
\hline 35 & 7.35 & 7.92 & 2.7 & 19.7 & 7.0 & 1.59 & 39.4 & 9.9 & 50.7 & sandy_loam \\
\hline 36 & 7.33 & 8 & 2.8 & 19.6 & 9.6 & 2.05 & 42.1 & 6.9 & 51 & sandy_loam \\
\hline 37 & 7.33 & 7.69 & 2.09 & 19.8 & 7.6 & 1.19 & 48.1 & 3 & 48.9 & Loam \\
\hline 38 & 7.36 & 7.8 & 2.5 & 20.1 & 9.0 & 2.30 & 39.4 & 12 & 48.6 & Loam \\
\hline 39 & 7.29 & 7.84 & 2.2 & 23.1 & 13.3 & 1.57 & 29.9 & 25.4 & 44.7 & sandy_loam \\
\hline 40 & 7.45 & 8.08 & 2.4 & 19.8 & 15.6 & 2.55 & 38.5 & 4.5 & 57 & sandy_loam \\
\hline 41 & 7.39 & 7.84 & 1.9 & 20.3 & 18.5 & 1.54 & 30.2 & 4.4 & 65.4 & sandy loam \\
\hline 42 & 7.43 & 8.18 & 2.18 & 20 & 6.2 & 1.06 & 13.1 & 17.9 & 69 & sandy_loam \\
\hline 43 & 7.34 & 8.21 & 1.8 & 21 & 8.6 & 0.86 & 12.9 & 14 & 73.1 & sandy loam \\
\hline 44 & 7.36 & 7.93 & 2.4 & 20.1 & 12.8 & 2.20 & 39.9 & 6.8 & 53.3 & sandy loam \\
\hline 45 & 7.26 & 8 & 1.3 & 20.6 & 9.4 & 2.00 & 43.8 & 5.6 & 50.6 & sandy_loam \\
\hline 46 & 7.41 & 8.2 & 1.06 & 23.5 & 10.4 & 1.52 & 18.3 & 20.6 & 61.1 & sandy_loam \\
\hline 47 & 7.38 & 7.95 & 2.64 & 24.1 & 6.8 & 2.27 & 41.3 & 6.8 & 51.9 & sandy_loam \\
\hline 48 & 7.4 & 8.1 & 2.73 & 23.6 & 8.8 & 1.59 & 30.1 & 16.1 & 53.8 & sandy_loam \\
\hline 49 & 7.51 & 8.09 & 1.32 & 24.3 & 23.7 & 1.47 & 19.2 & 13.5 & 67.3 & Loam \\
\hline 50 & 7.34 & 8.15 & 2.6 & 20.87 & 17.7 & 1.90 & 39.9 & 13.1 & 47 & Loam \\
\hline 51 & 7.21 & 8.07 & 1.792 & 25.3 & 9.4 & 2.35 & 43.6 & 8.7 & 47.7 & silty_loam \\
\hline 52 & 7.31 & 8.14 & 2.1 & 24.7 & 11.2 & 1.09 & 54.4 & 9.1 & 36.5 & Loam \\
\hline 53 & 7.34 & 7.96 & 2.1 & 25.1 & 7.6 & 2.55 & 42.9 & 11 & 46.1 & Loam \\
\hline 54 & 7.41 & 7.95 & 2.8 & 24.6 & 14.8 & 1.97 & 43.2 & 16.1 & 40.7 & Loam \\
\hline 55 & 7.42 & 7.83 & 2.7 & 24.6 & 11.7 & 2.02 & 36 & 13.8 & 50.2 & Loam \\
\hline 56 & 7.34 & 7.7 & 2.4 & 23.5 & 11.5 & 2.4 & 38 & 14.5 & 47.5 & Loam \\
\hline
\end{tabular}




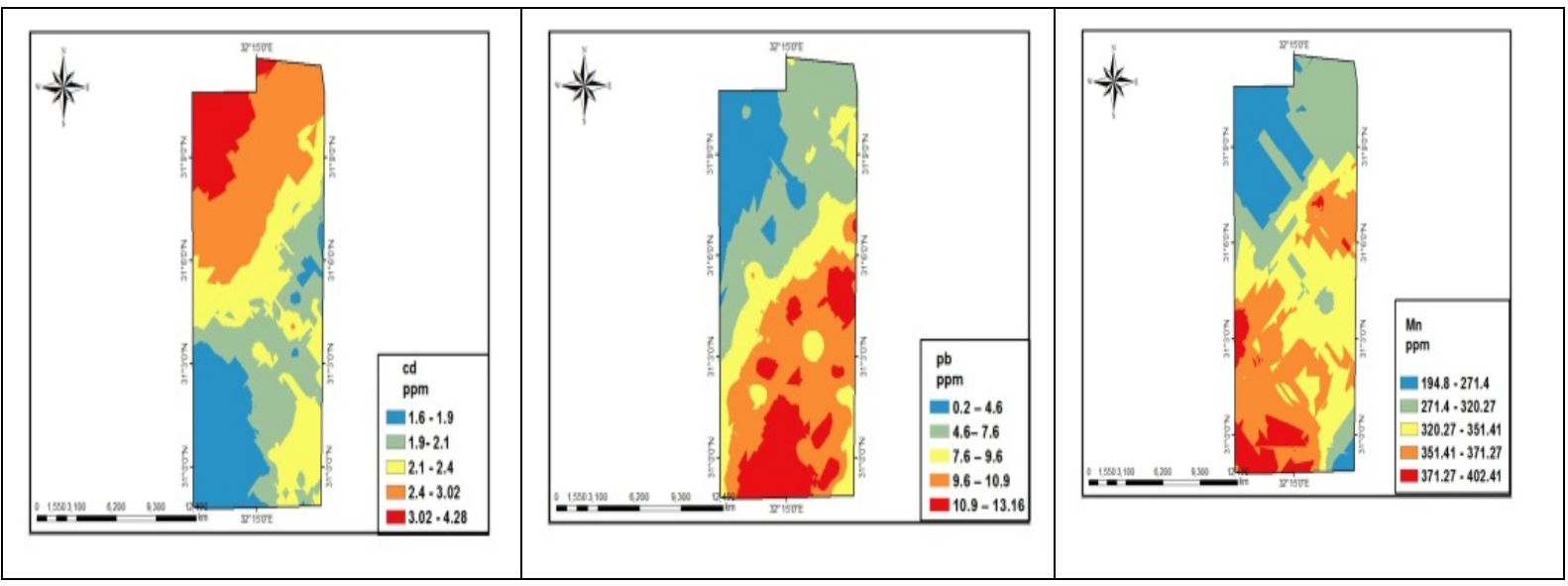

Fig. 3. Spatial distribution of selected heavy metals

Spectroradiometer (reflectance, R; absorption, A; first order derivative of absorption, A; and standardized reflectance). In the multiple regression setting, the response variable y (soil contamination) depends on not one but several explanatory variables: matrix $\mathrm{x}$ (spectral data) to estimate the concentration of heavy metals. The results showed the overall form of the ASD spectra is quite similar among the studied soil samples. Therefore stepwise multiple linear regression (MLR) is used to describe the correlation between concentration of heavy metals and their effects on spectral reflectance.

For calibration based on multivariate statistics, a stepwise regression procedure was used in order to limit the number of input variables. Variables were entered or removed from the model depending on the testes for hypothesis. As illustrated in Table 2 the ANOVA Test appear that the sum of squares of regression for all parameters are higher than residuals. In addition, the $F$ statistics at confidence level of $95 \%$, for (Cd) are higher than the number of samples selected and confidence level of $50 \%$, for $(\mathrm{Mn}, \mathrm{Pb})$ are smaller than the number of samples selected that means the relationship is not coincident and that there is genuine relationship between the reflectance and (Cd), and not genuine relationship between the reflectance and ( $\mathrm{Mn}$ and $\mathrm{Pb}$ ).

The values of Beta in all parameters are negative, which indicates that the relationship is an inverse one, meaning the spectral reflectance increase as the parameters content decreases.
Tolerance ( $T$ the percentage of variance in a given predictor that cannot be explain by the other predictor) for ( $\mathrm{Mn}, \mathrm{Cd}$ and $\mathrm{Pb})$ are $(0.77$, 0.86 and 0.83 ) which if close to (1) indicate that $100 \%$ of the relationship cannot be explained by other variables. (VIF Variance Inflation Factors) for $(\mathrm{Mn}, \mathrm{Pb}$ and $\mathrm{Cd})$ are (21.4, 22.1 and 26.5) big than (2) that indicate this variables are not collinearity which meaning two or more predictor variables in a multiple regression model aren't highly correlated.

The statistical parameters from the calibration processes of the optimal combinations are given the best predictive equations were chosen as the equation by MLR with the highest $\mathrm{R}^{2}$ as shown Table 3.

The changes occurred in reflectance values in different regions along with spectral curve, especially in near infrared (NIR) and visible region are associated with increasing heavy metals concentrations. As illustrated Table 3 spectral reflectance was 505, 490,1679, 1913 and $494 \mathrm{~nm}$ for Lead also1679, 506 and 1958 $\mathrm{nm}$ for manganese and 1705, 1917, 1161nm for cadmium. $\mathrm{R}^{2}$ was 0.51 and 0.73 and 0.91 for $\mathrm{Pb}$, $\mathrm{Mn}$ and Cd respectively.

The accuracy of quantitative analysis was evaluated by calculating the $\mathrm{R}^{2}$ value of a linear regression relating the measured soil heavy metals (forty samples) with the predicted from the models. The relationship between measured 
Table 2. Test the hypothesis to select the best model

\begin{tabular}{|c|c|c|c|c|c|c|}
\hline \multirow[t]{3}{*}{ Parameter } & \multicolumn{3}{|c|}{ ANOVA Test } & \multirow{3}{*}{$\begin{array}{c}\text { Standardized } \\
\text { Coefficients }\end{array}$} & \multicolumn{2}{|c|}{ Collinearity Statistics } \\
\hline & \multicolumn{2}{|c|}{ Sum of Squares } & \multirow[t]{2}{*}{$\mathbf{F}$} & & \multirow{2}{*}{$\begin{array}{c}\text { Tolerance } \\
\text { (T) }\end{array}$} & \multirow[t]{2}{*}{ VIF } \\
\hline & Regression & Residual & & & & \\
\hline$\overline{\mathbf{M n}_{\mathrm{ppm}}}$ & 135895.315 & 36230.624 & 30.944 & -2.585 & 0.77 & 21.4 \\
\hline $\mathbf{C d}_{\text {ppm }}$ & 8.553 & .821 & 118.019 & -2.795 & 0.86 & 22.1 \\
\hline $\mathbf{P} \mathbf{b}_{\text {ppm }}$ & 478.304 & 443.898 & 14.277 & -2.099 & 0.83 & 26.5 \\
\hline
\end{tabular}

Table 3. Models have been extracted by MLR with $\mathbf{R}^{2}$

\begin{tabular}{lcccc}
\hline Parameter & Equation & Wavelengths & $\mathbf{R}^{2}$ & spectral range \\
\hline Pb ppm & $13.39-$ & Where $\mathrm{x}_{1}, \mathrm{x}_{2}, \mathrm{x}_{3}, \mathrm{x}_{4}$ represent separately & 0.51 & Blue-Green - \\
& $33.8^{*} \mathrm{x}_{1}+35.8^{*} \mathrm{x}_{2-}$ & reflectance at wavelengths: & & Near Infrared \\
& $96.0^{*} \mathrm{x}_{3}+101.3^{*} \mathrm{x}_{4}$ & $505 \mathrm{~nm}, 490 \mathrm{~nm}, 1679 \mathrm{~nm}, 1913 \mathrm{~nm}$ 494nm & & \\
Mn & $466.28-1937.4^{*}$ & Where $\mathrm{x}_{1}, \mathrm{x}_{2}, \mathrm{x}_{3}, \mathrm{x}_{4}$ represent separately & 0.73 & Green- Near \\
& $\mathrm{x}_{1}+1002.53^{*}$ & reflectance at wavelengths: & & Infrared \\
& $\mathrm{x}_{2}+1389^{*} \mathrm{x}_{3}-410.24^{*}$ & $1679 \mathrm{~nm}, 506 \mathrm{~nm}, 1958 \mathrm{~nm}, 500 \mathrm{~nm}$ & & \\
& $\mathrm{x}_{4}$ & & & \\
Cd & $1.45+32.6^{*} \mathrm{x}_{1}-17.1^{*}$ & Where $\mathrm{x}_{1}, \mathrm{x}_{2}, \mathrm{x}_{3}$ represent separately & 0.91 & Near Infrared \\
& $\mathrm{x}_{2}-17.09^{*} \mathrm{x}_{3}$ & reflectance at wavelengths: & & \\
& & $1705 \mathrm{~nm}, 1917 \mathrm{~nm}, 1161 \mathrm{~nm}$ & & \\
\hline
\end{tabular}

and predicted values was plotted in Fig. 4. The result revealed a good relationship between the measured heavy metals and the predicted ones where, Cd, Mn and Cd have high accuracy with $\mathrm{R}^{2} \quad 0.94, \quad 0.70$ and 0.66 , respectively. The accuracy estimation illustrates the quantity of soil heavy metals content has been measured by traditional method (Atomic).

\section{Hazard Mapping of Heavy Metals}

Bahr El-Baqar drain receives untreated waste water starting from east of Cairo, at the discharge point of El-Gebel El-Asfar and then joined by Belbeis drain, down to the confluence with Qalubiya drain. The length of the main drain is 170 km discharges in El-Manzala Lake and has two main branches, Qalubyia drain and Bilbies drain. It receives and carries the greatest part of wastewater (about $3 \mathrm{BCM} /$ year) into Lake Manzala through a very densely populated area of the Eastern Delta passing through
Qalubyia, Sharkia, Ismailia and Port-said Governorates. Four main sources of pollutants which cause deterioration in Bahr El-Baqar are: The industrial activities in Shoubra El-Khema including metal production, food processing, detergents and soaps manufacturing, textile finishing and paper production; Industrial activities in Zagazig area; Waste water discharged from Belbeis drain to Bahr El-Baqar; and Domestic discharge received from rural areas around Bahr El-Baqar drain. Soil represents a major sink for heavy metals ions, which can then enter the food chain via plants or leaching into ground water. GIS can be used to assess the soil pollution potential. In order to prevent soil pollution before it occurs and avoid the future need for costly remediation efforts. The Geostatistical Analyst can be used to map the probability that any heavy metals values exceed the threshold. The heavy metals vulnerability maps for agricultural purposes are shown in 
Fig. 5. The whole area is divided into two classes on the basis of hazard, low and high
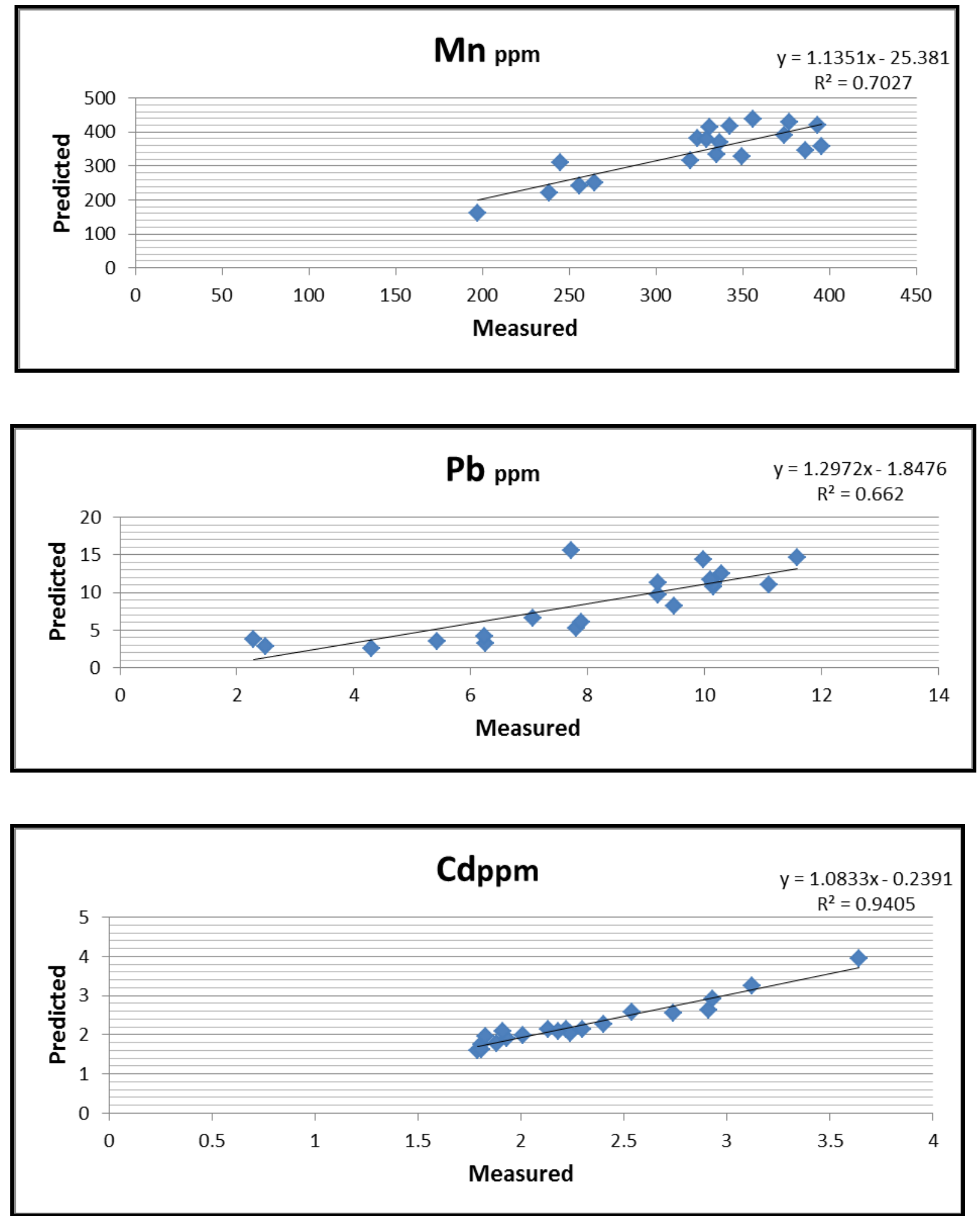

Fig. 4. Correlation between measured and predicted the selected heavy metals 


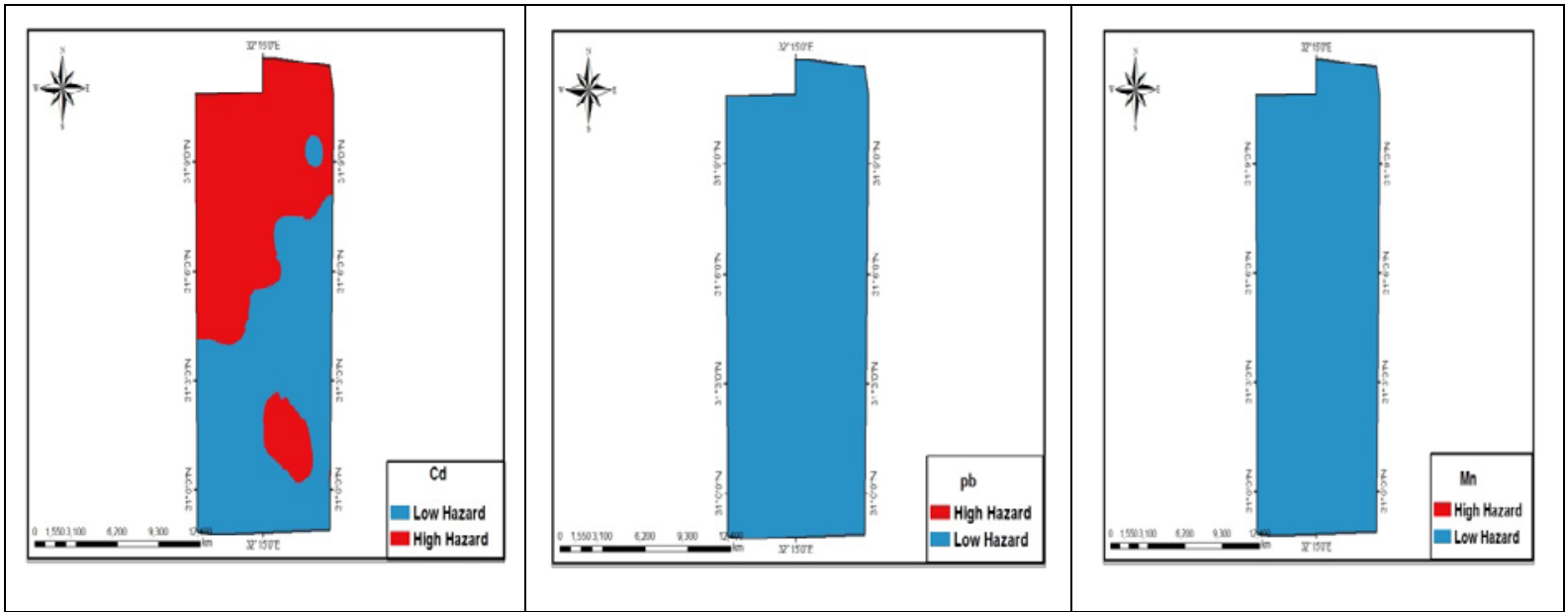

Fig. 5. Hazards of $\mathrm{Cd}, \mathrm{Pb}$ and $\mathrm{Mn}$

according to WHO (2009). Most of the soil samples fall in the low hazard classes. $\mathrm{Pb}, \mathrm{Mn}$, and $\mathrm{Cd}$ metals concentrations are under the threshold value in soils which falls in the low hazard category. However, only Cd falls in the high hazard category. The total study area (10791.08) faddans is contaminated with Cd.

\section{Conclusion}

This search using spectral reflectance to detect soil contamination in southern distreic of Port-Said Governorate. Heavy metals have been predicted from spectral reflectance by using MLR. The result show Spectrum data which taken in Vis-NIR range (350-2500 nm) and could be used to estimate the soil contamination with high accuracy the same in abstract. Therefore, Visible Near-infrared (Vis-NIR) reflection spectroscopy is cost and timeeffective that could be alternatives to the traditional methods of heavy metals analysis. In addition, this paper highlights the environmental hazards occurred southern Port-said Governorate, the results showed concentration of soil contamination by $\mathrm{Cd}, \mathrm{Mn}$, and $\mathrm{Pb}$ are under the threshold. Except for an area contaminated with Cd covering 10791.08 faddans. Due to insecticides, fungicides, sludge, and commercial fertilizers us aye.

\section{REFERENCES}

Abu Zeid, M. (2011). Egyptian policies for using low quality water for irrigation. Water Res. Center- Cairo-Egypt. http://www. docstoc. com/ docs/ 68231841 / Egyptian- policies-forusing - low-quality-water-for-irrigation.

Assia, A.E., S.A. Aboulroos, A.A. Saoud and M.A. Ali (2004). Aquatic Plants For Bioremediation of waste water. Eighth Int. Water Technol. Conf., IWTC8, Alex., Egypt.

Bandyopadhyay, P (2007). Soil Analysis. Hardcover ISBN- 13: 286.

Cohen, J., P. Cohen, S.G. West and L.S. Aiken (2003). Applied multiple regression/ correlation analysis for the behavioral sciences. $\left(2^{\text {nd }} E d\right.$.) Hillsdale, NJ: Lawrence Erlbaum Associates.

Kooistra, L., R. Wehrens, R.S. Leuven and L.M. Buydens (2001). Possibilities of visible-nearinfrared spectroscopy for the assessment of soil contamination in river floodplains. Analytica Chimica Acta., 446 : 97-105.

Loranger, S. and J. Zayed (1994). Manganese and lead concentrations in ambient air and emission rates fromunleaded and leaded gasoline between 1981 and 1992 in Canada: a comparative study. Atmos. Environ., 28: 1645-1651.

Qadir, M., B.R. Sharma, A. Bruggeman, R. Choukr-Allah and F. Karajeh (2007). Nonconventional water resources and opportunities for water augmentation to achieve food security in water scarce countries, Agric. Water Manag., 87 : 2-22. 
Meul, M. and M. Van Meirvenne (2003). Krigining soil texture under different types of nonstationarity. Geoderma, 112 : 217-233.

Mohamed, E.S., E.G. Morgan and I. Kovda (2011). Assessment of soil degradation in the eastern part of the Nile Delta. Moscow Univ. Soil Sci. Bulletin, V (66): 86-92.

Omran, E.E. and A.A. Abd El-Razek (2012). Mapping and screening risk assessment of heavy metals concentrations in soils of the Bahr El-Baker Region, Egypt, J. Soil Sci. and Environ. Manag., 6 (7): 182-195.

Park, J.H. and W.S. Shin (2006). Immobilization of $\mathrm{Pb}$ contamined soil using Modified clay. Wat. Practice and Technol., 1: 1-10.

Ramadan, A.A. (2003). Heavy metal pollution and biomonitoring plants in Lake Manzala, Egypt. Pak. J. Biol. Sci. 6: 1108-1117.

Saad, A.K. (1997). Environmental hydrogeologic impacts groundwater withdrawal in the eastern Nile Delta region with emphasis on groundwater pollution potential. Ph. D. Thesis, Inst. Environ. Studies. Ain Shams Univ., 232.

Schwartz, G., G. Eshel and E. Ben-Dor (2011). Reflectance spectroscopy as a tool for monitoring contaminated soils, soil contamination, msc simone pascucci (Ed.), ISBN: 978-953-307-647-8.

WHO Europe (2009). Levels of lead in children's blood fact sheet 4.5 (RPG4_Chem_Ex1) Copenhagen: World Health Organization Regional Office for Europe. Available at: www.euro. who.int/_data/ ssets/pdf_ file/ 0003/97050/4.5.-Levels-of-lead-in-childrensblood-EDITING_ layouted. pdf.

Yun, L. (2003). Possibilities of assessing heavy metal contamination of soil in the sajo river flood plains(Hungary) using reflectance spectroscopy. 


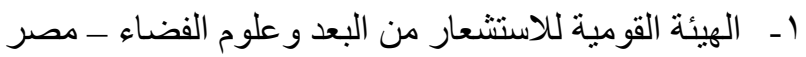

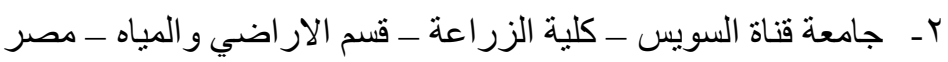

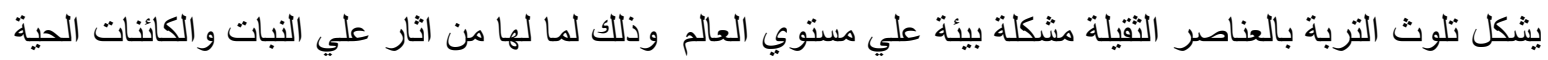

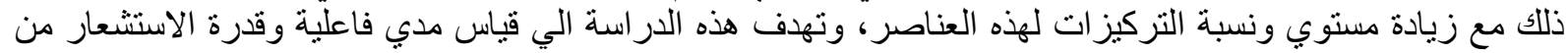

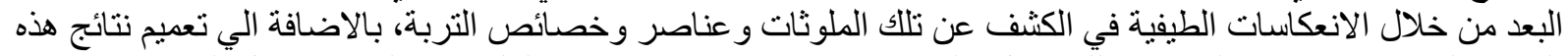

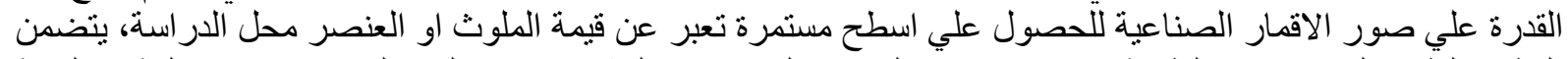

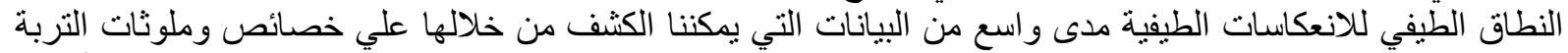

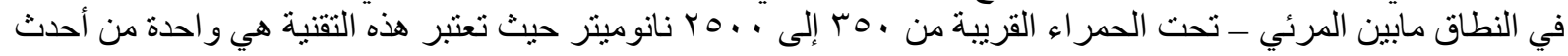

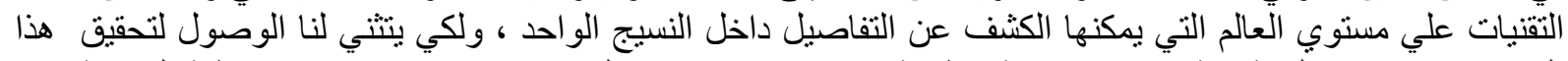

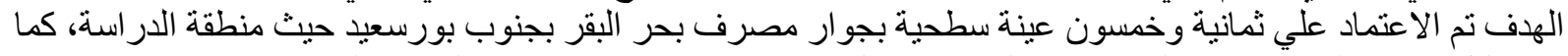
تم تحليل ثلاث ملوثات وهي الرصات

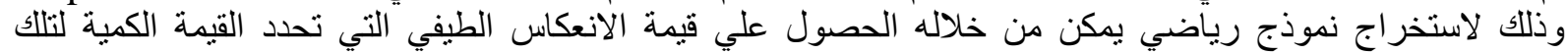

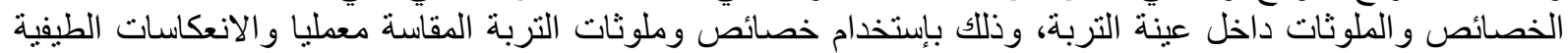

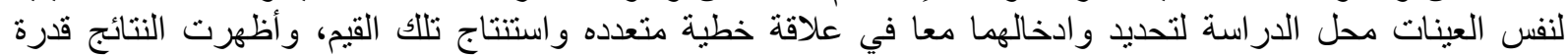

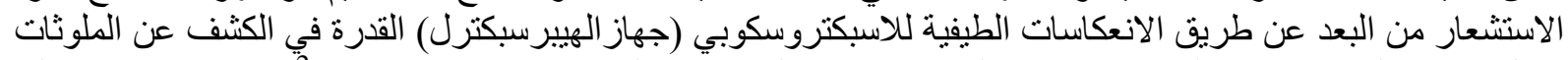

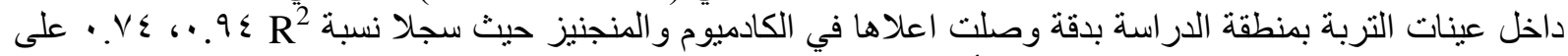

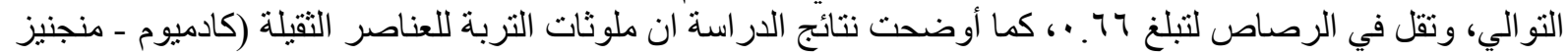

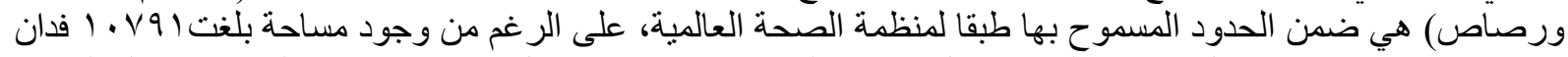

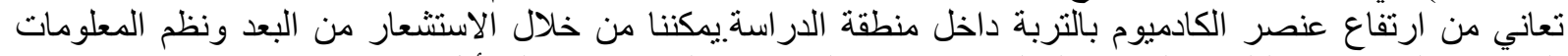

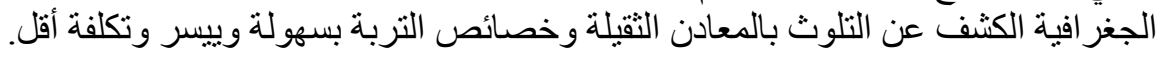

